\author{
Коминова Оксана Михайловна \\ Магистрант кафедры бухгалтерского учета и налогообложения \\ Российский экономический университет имени Г.В.Плеханова, \\ Российская Федерация, г. Москва, 117997, Стремянный пер., 36 \\ E-mail:kominova0825@mail.ru
}

\title{
ПРАВОМЕРНОСТЬ ПРЕДЬЯВЛЕНИЯ ИСКОВ НАЛОГОВЫМИ ОРГАНАМИ О ПРИЗНАНИИ СДЕЛОК НЕДЕЙСТВИТЕЛЬНЫМИ И НАЛОГОВЫЕ ПОСЛЕДСТВИЯ В СВЯЗИ С РЕСТИТУЦИЕЙ
}

\begin{abstract}
Аннотация: Данная статья посвящена рассмотрению правомерности предъявления исков налоговыми органами о признании сделок недействительными, а также налоговых последствий в связи с реституцией. В ходе анализа судебной практики было выявлено две судебные позиции: одни суды предоставляют налоговым органам право предъявлять иски в суд о признании сделки недействительной, в то время как другие суды считают, что такое право у налоговых органов отсутствует. Также, в ходе анализа были выделены основные налоговые последствия в отношении участников сделки в связи с признанием судом сделки недействительной. Статья выполнена под научным руководством к. э. н., доцента Дюжова А.В., кафедра бухгалтерского учета и налогообложения РЭУ им. Г.В. Плеханова.
\end{abstract}

Ключевые слова: Нормативно-правовые акты, реституция, сделка, налоговые последствия, налоговый учет.

Введение. Экономические субъекты при осуществлении хозяйственной деятельности сталкиваются с оспариванием действительности заключенных сделок. При признании сделки недействительной у налогоплательщиков возникает риск предъявления претензий со стороны налоговых органов касательно пересмотра налоговых последствий. Вопрос о правомерности предъявления исков налоговыми органами о признании сделок недействительными на сегодняшний день регулярно возникает в практике арбитражных судов, где нет однозначной позиции по данной проблематике.

Основная часть. "Недействительная сделка не влечет юридических последствий за исключением тех, которые связаны с недействительностью, и недействительна с момента ее совершения" [1] - в соответствии со ст. 167 Гражданского кодекса Российской Федерации (далее - ГК РФ). Следовательно, в соответствии с гражданским законодательством, если суд признал сделку недействительной, обе стороны должны возвратить друг другу все полученное имущество по этой сделке, то есть вернуться в исходное положение, в котором они прибывали до наступления сделки.

Сущность проблемы сводится к тому, что налоговое законодательство не содержит положений, которые регламентировали бы порядок отражения последствий после признания сделки недействи- тельной, в отличие от гражданского законодательства. Каковы полномочия налоговых органов в данной области? Должны ли налогоплательщики пересчитывать налоговые обязательства, в частности, по налогу на прибыль? Какие налоговые последствия возникают при признании сделки недействительной у продавца и покупателя в части восстановления сумм налога на добавленную стоимость (далее - НДС)? Все эти и многие другие вопросы на сегодняшний день являются открытыми. Для того чтобы ответить на все вышеперечисленные вопросы обратимся к судебной практике и проанализируем ее [2, 3].

Согласно ст. 166 ГК РФ, законодательство предусматривает ограниченный круг лиц, который вправе предъявлять иск в суд о применении последствий недействительности сделок, в зависимости от их вида. Оспоримые сделки имеют ограниченный круг лиц, которые вправе прямо названы в законодательстве (например, по иску родителей, усыновителя, попечителя, - ст. 175 ГК РФ). В случае ничтожных сделок прямых ограничений нет суд может признать иск любого заинтересованного лица. Однако, что следует понимать под «заинтересованным лицом», законодательство не разъясняет, поэтому суды в каждом конкретном случае решают, является ли данное лицо заинтересованным или нет [4]. 
В ходе анализа судебной практики было выявлено две судебные позиции: одни суды предоставляют налоговым органам право предъявлять иски в суд о признании сделки недействительной, в то время как другие суды считают, что такое право у налоговых органов отсутствует (Таблица 1. Судебные позиции касательно прав налоговых органов предъявлять иски в суд о признании сделки недействительной).

Таблица 1. Судебные позиции касательно прав налоговых органов предъявлять иски в суд о признании сделки недействительной

\begin{tabular}{|c|c|}
\hline Судебные позиции & Основание судебной позиции/ судебная практика \\
\hline $\begin{array}{l}\text { Налоговые органы наделены правом } \\
\text { предъявлять иски в суд о признании } \\
\text { сделки недействительной }\end{array}$ & $\begin{array}{l}\text { 1. Ст.7 п. } 11 \text { Закон РФ от } 21.03 .1991 \text { №943-1«О налоговых органах РФ» } \\
\text { (Постановление ФАС ПО от 28.06.2002 №А49-1117/02-0/4-9) } \\
\text { 2. ст. } 31 \text { НК РФ } \\
\text { (Постановление ФАС МО от 08.04.02 г. по делу №КГ-А40-/1880-02; } \\
\text { Постановление ФАС ПО от 28.06.2002 №А49-1117/02-0/4-9) } \\
\text { 3. ст. } 169 \text { ГК РФ } \\
\text { (Определение от } 25.07 .2001 \text { г. №138-О; } \\
\text { определение от 10.01.2002 г. №4-О; } \\
\text { определение от 14.05.2002 г. № 108; } \\
\text { определение от } 25.07 .2002 \text { г. №138-О; } \\
\text { определение от 04.12.2003 №441-О; } \\
\text { определение от } 08.06 .2004 \text { № 225-О; } \\
\text { Постановление ФАС СЗО от 12.09.2003 № А05-920/03-24/23 }\end{array}$ \\
\hline $\begin{array}{l}\text { Налоговые органы ограниченны в пра- } \\
\text { ве на предъявление иска в суд о призна- } \\
\text { нии сделки недействительной }\end{array}$ & $\begin{array}{l}\text { 1. ст. } 31 \text { НК РФ } \\
\text { (Постановление ФАС СЗО от } 15.04 .02 \text { г. по делу № А56-21663/01; } \\
\text { Постановление Пленума ВАС РФ от } 28.02 .01 \text { г. № } 5 \text { «О некоторых во- } \\
\text { просах применения части первой НК РФ»); }\end{array}$ \\
\hline
\end{tabular}

Различные точки зрения по данному вопросу возникают в связи с разным толкованием ст. $31 \mathrm{Ha-}$ логового кодекса Российской Федерации (далееНК РФ). С одной стороны, в судебной практике выработан подход, обусловленный прежде всего тем, что в соответствии ст. 31 НК РФ, ст. 7 Закона РФ от 21.03.1991 №943-1 “О налоговых органах РФ”, а также ст. 169 ГК РФ налоговые органы наделены правом предъявлять “иск о признании сделки недействительной и взыскании в доход государства всего полученного по этой сделке”. Указанная точка зрения обусловлена тем, что в соответствии со ст. 31 НК РФ налоговые органы наделены рядом прав, в том числе и правом на подачу исков в суд. Данное право конкретизируется в п. 11 ст. 7 Закона РФ от 21.03.1991 № 943-1 “О налоговых органах РФ”, где закон прямо предусматривает "право налоговых органов предъявлять в суды иски о признании сделок недействительными и взыскании в доход всего полученного по таким сделкам" $[5,6]$.

Данная позиция неоднократно подтверждалась Конституционным Судом РФ, со ссылкой также на ст. 169 ГК РФ, на основании которой налоговые органы наделены правом предъявлять в суд требования, в том числе и иски о признании сделок недействительными, в целях обеспечения баланса государственных и частных интересов, если такая сделка заведомо носила антисоциальный характер, что противоречит основам правопорядка и нравственности $[7,8]$. С другой стороны, позиция суда основана на том, что налоговое право должно подчинятся четким правилам, так как данное право относится к публичной отрасли и все, что четко не прописано в налоговом законодательстве, не вправе осуществляться в рамках властных отношений.

В ходе признания сделки недействительной возникают налоговые последствия как у продавца, так и у покупателя. В отношении налога на прибыль покупатель после признания судом сделки недействительной должен восстановить ранее начисленную амортизации по выбывшему основному средству, после чего подать уточненные декларации за те периоды, в которых отражались расходы в виде амортизационных отчислений, - письмо Министерство финансов РФ от 20.03.2015 №03-07-11/15448.

Однако, когда именно организация должна подать уточненную декларацию, Министерство финансов РФ не уточняет. Ведь может возникнуть ситуация, когда имущество было приобретено в 2016 году, суд признал сделку недействительной в 2017 году, а возврат имущества произошло только в 2018 г. Принимая во внимание Постановление ФАС УА от 12.05.2009 №Ф09-2876/09С3 по делу № А 07-6358/2008-А-ДГА, покупатель должен произвести корректировку налоговой базы по налогу на прибыль за предыдущие налоговые периоды после 
фактического возврата имущества, после чего подать уточненные декларации в том периоде, когда произошла реституция.

В тоже время, во избежание налоговых рисков начисление амортизации по основным средствам стоит прекратить с того момента, когда суд признал сделку недействительной, и до момента, когда имущество возвращается продавцу. В соответствии c налоговым законодательством экономический субъект имеет право уменьшить общую сумму НДС на установленные ст. 171 НК РФ налоговые вычеты. Следовательно, суммы НДС, уплаченные в бюджет при реализации товаров и предъявленные покупателю продавцом, подлежат вычету в случае возврата этих товаров. Указанные нормы НК РФ следует применять и в случае признания судом сделки недействительной, - согласно официальным разъяснениям Министерство финансов РФ от 20.03.2015 №03-07-11/15448 и ФНС России от 06.05.2015 № CA-4-3/7819@.

В отношении налога на прибыль продавец после признания судом сделки недействительной должен исключить из доходов выручку, отраженную ранее по данной сделке, тем самым устранить искажение налоговой базы по налогу на прибыль. В соответствии с налоговым законодательством (п. 1 ст. 54 НК РФ), корректировка налоговой базы производится в случае обнаружения ошибок (искажений) [9].

Вместе с тем НК РФ предусматривает случаи, когда организация может произвести корректировки налоговой базы в момент обнаружения ошибок (без подачи уточненной декларации), если период совершения ошибки невозможно определить и допущенные искажения привели к излишней уплате налога. С одной стороны, ФНС в письме от 28.11.2017 № СД - 4-3/24087@ признает правомерным, ссылаясь на п. 1 ст. 54 НК РФ:

1) предоставления налогоплательщиком уточненной декларации за прошедший налоговый период вследствие признания судом сделки недействительной, и

2) перерасчет налоговой базы и суммы налога за налоговый период, в котором была совершена (выявлена) ошибка.
Однако, в налоговом законодательстве отсутствует разъяснение, что понимается под ошибками (искажениями). Обратимся к нормам ПБУ 22/2010 “Исправление ошибок в бухгалтерском учете и отчетности", на основании п.1 ст.11 НК РФ [10]. Из данного документа следует, что ошибкой признается "неправильное отражение (не отражение) фактов хозяйственной деятельности, которые могут возникнуть, в связи:

- с неправильным применением бухгалтерского законодательства, учетной политики, использованием информации, а также с классификацией или оценкой фактов хозяйственной деятельности;

- с неточностями в вычислениях, и;

-недобросовестными действиями должностных лиц организации.

Заключение. Таким образом, из общих норм НК РФ и правил бухгалтерского учета следует, что признание сделки недействительной не является основанием для признания отраженных по этой сделке в регистрах бухгалтерского учета фактов хозяйственной жизни, на основе которых исчисляется налоговая база, ошибками (искажениями), подлежащими исправлению. С другой стороны, в арбитражной практике выработан иной подход, обусловленный, прежде всего, тем, что в данном случае речь идет не об ошибках (искажениях), а о признании сделки недействительной.

1) Налогоплательщик обязан формировать доходы, связанные с реализацией в период их фактической реализации; все последующие изменения, в нашем случае признание судом сделки недействительной, совершенные в соответствующем налоговом или отчетном периоде, подлежат учету как новые факты хозяйственной жизни.

2) Признание сделки недействительной и последующая реституция "не может повлечь искажение в бухгалтерском учете реальных фактов их хозяйственной деятельности, в связи с чем после фактической реституции организация имеет право отразить такой возврат в составе расходов, а, следовательно, уменьшить налоговую базу того периода, в котором осуществлены операции по возврату объекта договора".

Список использованных источников

1. Определение Верховного Суда Российской Федерации от 26.03.2015 №305 -КГ 15-965.

2. Определение Верховного Суда Российской Федерации от 09.10.2014 № 309-КГ 14-2300.

3. Постановление от 01.07.1996 №6/8 Высшего Арбитражного Суда РФ «О некоторых вопросах, связанных с применением части первой Гражданского кодекса РФ».

4. Зверев А.А., Львов И.В., Александров М.В. Преимущества использования лизинговых операций в коммерческой деятельности предприятий // В сборнике: Математические модели и их приложения сборник научных трудов. Чебоксары, 2011. С. 213-217.

5. Муртузалиева С.Ю. Система государственного регулирования внешнеэкономических связей: региональный аспект // Региональная экономика: теория и практика. 2007. № 8. С. 68-74. 
6. Дмитриева И.М. [и др.] Бухгалтерский финансовый учет: Учебник для СПО/под ред. И.М. Дмитриевой. -М.: Юрайт, 2016. -539 с.

7. Косов М.Е. Равновесие экономической системы/Монография Российский государственный торгово-экономический университет. РГТЭУ, Москва 2012 год. С. 295.

8. Посаднева Е.М. Особенности организации ведения упрощённой системы бухгалтерского учета и отчетности в РФ // Экономика и предпринимательство. 2016. № 3-1 (68). С. 820-823.

9. Бухарева Л.В., Городецкая М.И., Дмитриева И.М. [и др.] Бухгалтерский финансовый учет. Учебник/Москва, Юрайт, 2016. Сер. Бакалавр. Академический курс (2-е изд.)

10. Блошенко Т.А. Налоговый аспект при хеджировании рисков // Проблемы анализа риска. - 2013. - Т. 10. №2. C. $72-79$.

\author{
Kominova Oksana Mikhailovna \\ Student of Master Degree \\ Plekhanov Russian University of Economics \\ Russian Federation, 117997, Moscow, Stremyanny lane, 36 \\ E-mail: kominova0825@mail.ru
}

\title{
LEGITIMACY OF PROVISION OF CLAIMS BY TAX AUTHORITIES ON THE RECOGNITION OF TRANSACTIONS AS INVALID AND TAX EFFECTS CONNECTED WITH RESTITUTION
}

Summary. This article is devoted to the consideration of the legality of the filing of claims by tax authorities for the recognition of transactions as invalid, as well as the tax consequences in connection with restitution. The analysis of judicial practice revealed two judicial positions: some courts give tax authorities the right to send claims to the court asking to declare the transaction invalid, while other courts believe that tax authorities have no such right. In addition, in the course of the analysis, the main tax consequences for the participants in the transaction were identified in connection with the court's recognition of the transaction as invalid.

Keywords: regulatory legal acts, restitution, transaction, tax consequences, tax accounting. 